Acta Technologica Agriculturae 3

Nitra, Slovaca Universitas Agriculturae Nitriae, 2016, pp. 63-69

\title{
INFLUENCE OF RC ELEMENT WIRING IN ELECTRICAL CIRCUIT ON ELECTROMECHANICAL THERMOSTAT CONTACT WEAR
}

\author{
Peter HAAS*, Milan KADNÁR, Juraj RUSNÁK, František TÓTH, Dušan NÓGLI \\ Slovak University of Agriculture in Nitra, Slovak Republic
}

\begin{abstract}
Contact wear caused by electric arc during electric contact make (cut-in) and break (cut-out) has the direct impact on the contact lifetime. The RC element wired parallelly to the contact will eliminate or reduce the arcing and subsequently extend the lifetime. Comparative tests of the two sets of identical Danfoss 077B electromechanical thermostats have been carried out. In the first batch, standard thermostats were tested. In the second batch, the same thermostat types, but with RC elements wired parallel to thermostats main contacts were tested. Measurement has not proven any improvement of the contact wear. Temperature drift and change of the critical dimension caused by contact wear were very similar in the both cases. Thus, the application of RC element is considered not reasonable measure for reduction of contact wear of electromechanical thermostats.
\end{abstract}

Keywords: RC element; electric arc; electromechanical thermostat; contact system; contact wear; temperature drift; contact bounce

Contacts of electromechanical thermostats are exposed to contact burning due to switching of the electric load. In proportional thermostats, the point of contact break (contact cut-out) is defined by the Cut-out temperature. This point is called "A-measure" in Danfoss 077B thermostat. As the other temperature parameters are dependent on the Cut-out temperature, it provides a base for definition of all the thermostat temperatures. In ideal situation, contact cutout occurs in the same point every time.

Burning of the contacts causes evaporation of the contact layer. Consequently, this moves Cut-out point from its original position and causes temperature change during the thermostat lifetime. Thermostats are always becoming colder over the years - their temperatures are colder than those original set by the manufacturer. It may happen that due to the contact burning, the appliance will not be able to reach the temperature which is too cold to cut-out the thermostat. Thermostat contact system will remain Cut-in and the appliance compressor will become controlled by thermal protector instead of thermostat. The appliance will appear to be running constantly. When overheated, it will be Cut-out by thermal protector.

Thermostat producers are trying to avoid this problem by combining 2 solutions. The first solution includes the appropriate set-up of the spring forces and A-measure in order to break and make the contact as fast as possible. Usually, all moving parts inside the contact system have the spring characteristic, too. The second solution includes the appropriate choice of material and its size for the contact surfaces. Nowadays, $\mathrm{AgSnO}_{2} 88 / 12$ is widely used in contact systems (Kratzshmar et al., 2010). Tin oxide grains cause the deterioration of the silver layer conductivity, however, its main and important function is to reduce the burnout of the silver.
10-15 years of thermostat lifetime is normally expected by refrigeration appliance producers, but with a different parameter set-up. There is no general standard how to define the thermostat lifetime test parameters that can be referred to by everyone. Standard dealing directly with appliances is very general (IEC, 1999). Approval authorities $B E A B$ and UL defined a minimum lifetime for thermostats based on standards EN/IEC 60730-1 (IEC, 1999) and UL873 (UL, 2010). But the standards differ in required test cycles and in methods of testing. Danfoss AP has based its testing on EN/IEC 60730-1 and thus the conditions of the tests are more demanding than are the standards or requirements of customers (Danfoss, 2012)

\section{Normal contact operation}

Contact systems of thermostats are designed to break and make properly in a very short time. Contact wear occurs every time the electromechanical contacts are broken (cut-out) or made (cut-in) (Althouse et al., 2004). When the contacts are broken, there is a very small gap in between the contacts for a short time and an electrical arc is initiated across the gap. Arc causes contact wear and generates a certain amount of radio frequency interference to the air and noise to the power supply system (Danfoss, 1998).

When electric loads are high, amount of heat is generated in the areas where the contacts meet and the contact material can melt. This heat generation comes mainly from the energy content of the arc formed when the current is cut-in. It is important that this does not lead to local contact welding and consequent obstruction of the cut-out function. One way of avoiding contact welding is to provide a certain amount of oxygen (in a form of oxide) to the contact surface layer (e.g. $\left.\mathrm{AgSnO}_{2}\right)(\mathrm{Kratzshmar}$ et al., 2010). 
During make, contact wear can deteriorate by contact bounce (Kratzshmar et al., 2010). The most important factor in achieving good electrical switch characteristic is the time of contact bounce within the unit concerned. Bounce time is the time it takes for a pair of contacts take to stop bouncing after a make (cut-in) function (a useful analogy is a hammer and an anvil). Typical bounce times are measured within the range 1-10 ms. During some of the bounce time, when the contacts are broken, an amount of energy UARC . ILRA is generated. This may lead to light contact welding (Danfoss, 1998).

\section{Contact operation with RC element}

The most popular and commonly used method of electric arc suppression is to connect a resistor-capacitor (RC) element as shown in Figure 1. The preferred method is to connect it parallel to the contacts we want to protect. The main benefit of using the RC element is reduction of the electromagnetic interference (EMI), noise emitted to the radio frequencies and to the power supply. On top of that, RC element will improve the contact lifetime due to reduction of arcing.

When the contact is broken, the voltage across the discharged capacitor becomes zero and the transient voltage starts charging the capacitor. In the meantime, the gap of the contact is steadily widened, and by the time the capacitor is charged to its full potential, the contact gap is widened beyond the minimum breakdown potential of air, thus preventing the arcing. When the contact is made, the inrush current from the capacitor may damage the contact, and here, the resistance is needed to limit the maximum current during the contact make. The larger the capacitance, the greater is the transient suppression. However, when the contact is made, the additional energy stored in the capacitor has to be discharged through the contact (Pancon, 2015).

\section{Experimental procedure}

It was determined to execute the comparative Electric Lifetime Test according to instruction 077R0422 ver. 09. $A$ reference set of $077 \mathrm{~B}$ thermostats (10 pcs) and set of

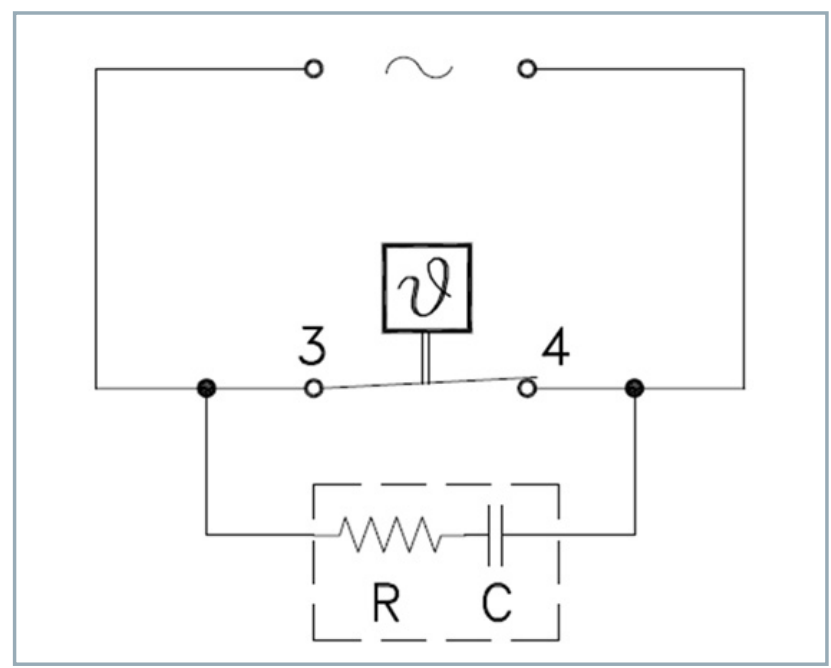

Figure 1 RC Element parallel wiring to thermostat main contact

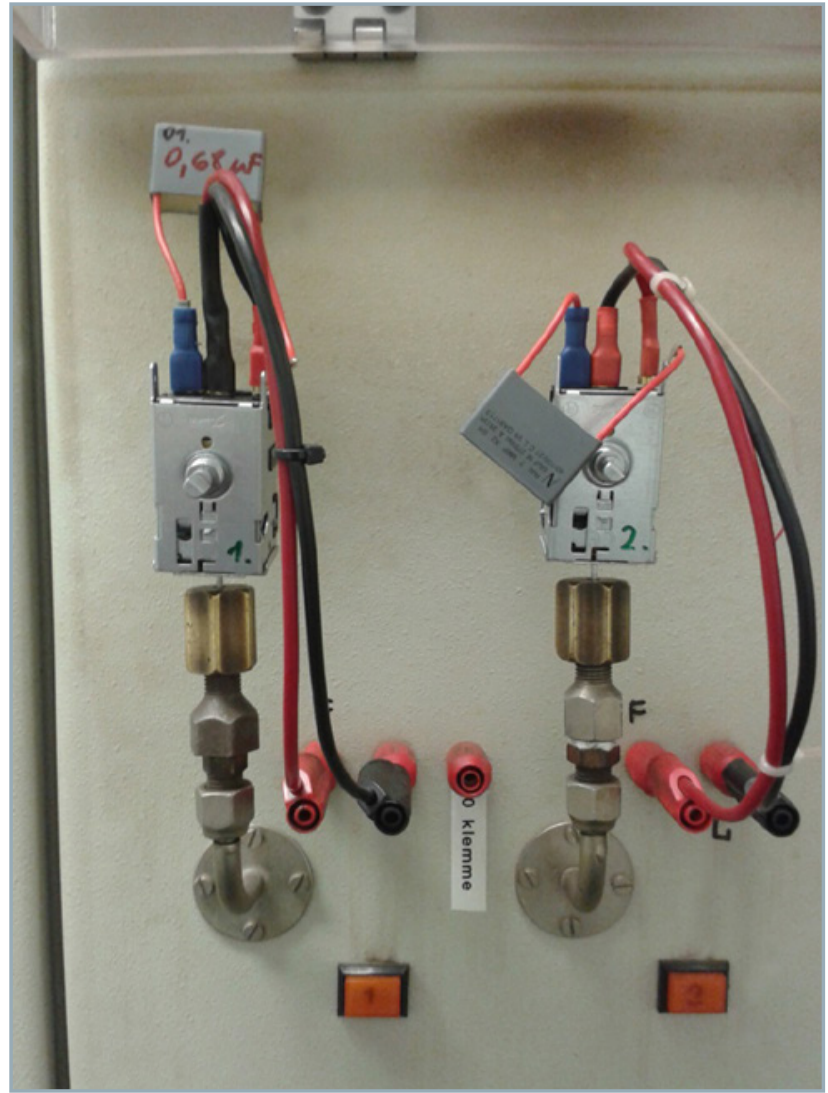

Figure 2 Samples seated in the tester (test 01)

077B thermostats with 2 types of RC element $(5+5$ pcs) were compared. Parameters of the thermostats and the measurements were the same. The only difference was that the RC elements in the second set were used. The goal was to compare the temperature drift reduction of the A-measure of the 3 options after the electric lifetime test. Evaluation of the temperature drift shall prove whether the RC element has positive influence on the thermostat contact wear or not.

Electric Lifetime Test checks the ability of the thermostat main electric contact to maintain its function over its lifetime at defined cycles and defined electric load (Danfoss, 2012). Thermostat contacts are exposed to electric arc, mainly during contact breaking. Electric arc causes a burning of the contact layer material. In proportional thermostats, this leads to decreasing of so called A-measure. This measure defines the Cut-out point of the thermostat and its decrease results into gradual decrease of the Cut-out temperature. Electric Lifetime Test checks the rate of the temperature change during the thermostat lifetime because of the contact burning out.

\section{Electric Lifetime Test parameters}

For both tests, Panel 1 of standard Danfoss AP equipment for Electric Lifetime Test was used. Thermostats are cycled by compressed air and main contacts are plugged to the specified load. The first $50 \mathrm{~ms}$ with inductive load $(\cos \varphi=$ $0.60)$ simulates the start of the appliance compressor. Next 950 ms with mostly resistive load $(\cos \varphi=0.95)$ simulates the standard running conditions of the compressor (UL, 2010; IEC, 1999). The cycle ends after $4 \mathrm{~s}$ with Cut-out. 


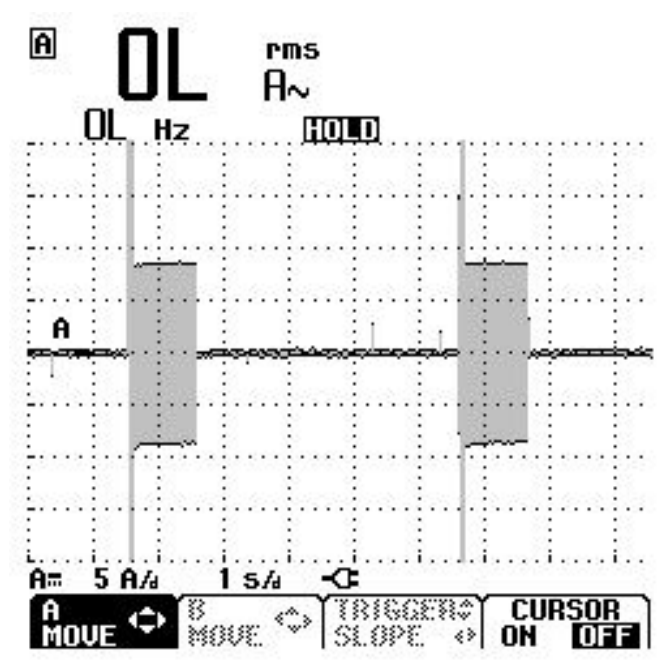

Figure 3 Cycles of tester scan (FLA/LRA/Cut-out)

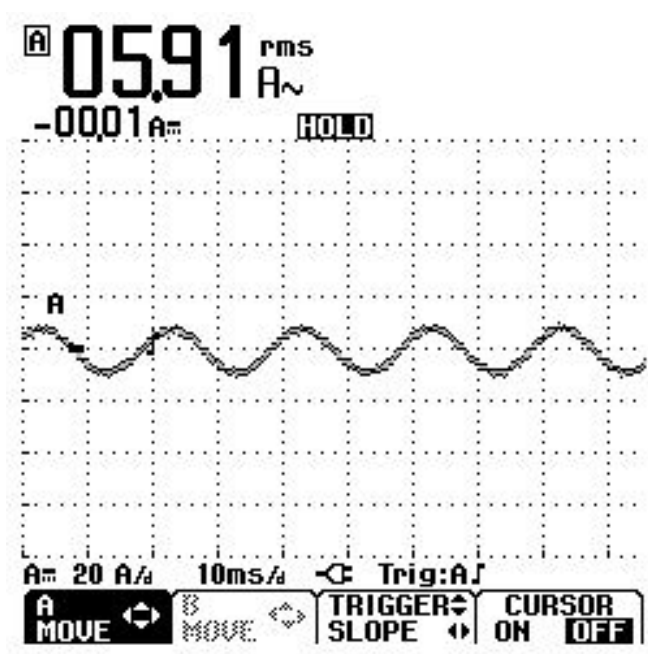

Figure 4 Full load amp (FLA) main contact

\section{${ }^{\square} 00.05_{\mathrm{A} \sim}^{\mathrm{mos}}$}

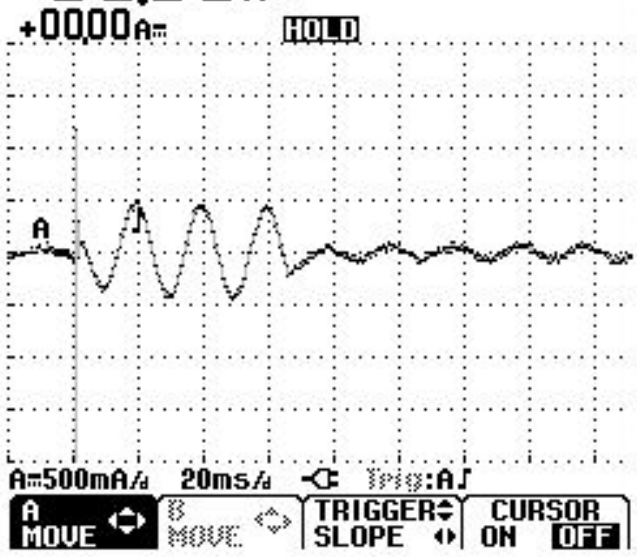

Figure 5 RC Element electric current curve
Thermostats are tested with rated electric current, however, contemporary compressors are much more efficient and most of them can run with electric current less than $1 \mathrm{~A}$. Scan of the pressures at defined cycles and recalculation to temperatures is done by test equipment (Danfoss, 2012):

- 10 thermostats in one test panel.

- Thermostats adjusted to nominal pressure values \pm 0.01 bar.

- Electric voltage $230 \mathrm{~V} / 50 \mathrm{~Hz} \pm 10 \%$ RMS.

- Make (Cut-in) time $1 \mathrm{~s}$ :

- 50 ms electric current LRA 36 A, $\cos \varphi=0.60$ (LRA Locked Rotor Amps),

- 950 ms electric current FLA 6 A, $\cos \varphi=0.95$ (FLA Full Load Amps).

- Break (Cut-out) time $4 \mathrm{~s}$.

\section{Tested thermostats}

Standard thermostats 077B6000 designed for tests by approval authorities were tested. $077 \mathrm{~B} 6000$ belongs to 077B6 family of Danfoss 077B thermostat. 077B6 thermostats are constant Cut-in thermostats, used to control a single compressor cooling circuit of double-door appliance (freezer + cooler). Electric current rating of 077B6000 is 6/36 A (FLA/LRA). Before testing, all measured parameters of the thermostat sub-assemblies and thermostat pressures (temperatures) were adjusted near the nominal values. Thermostat temperatures were recalculated to respective pressures according to used charge (Danfoss, 2006). 077B6000 parameters:

- adjusted in Warm position for R290 filling media parameters;

- cut-in $\quad+3.0^{\circ} \mathrm{C}->4.28$ ato $(5.21 \mathrm{bar})$;

- cut-out $-20.0^{\circ} \mathrm{C}->1.46$ ato (2.45 bar);

- ato $\left(\mathrm{kp} / \mathrm{cm}^{2}\right)$ - technical atmosphere pressure (absolute - pressure over barometric pressure).

\section{Measured thermostat parameters:}

- pressures (re-calculated to respective temperatures) are loaded for Cut-in and Cut-out at 0, 2000,25000 , 100 000, 200 000, 300000 cycles;

- function of the main contact;

- A-measure (before and after the test).

\section{Used RC elements:}

1. ARCOTRONICS (KEMET) R. $46 ; 39 \Omega+0.68 \mu \mathrm{F} ; 275 \mathrm{~V} / 50 \mathrm{~Hz}$, X2 Class.

2. ARCOTRONICS (KEMET) R. $46 ; 39 \Omega+1.00 \mu \mathrm{F} ; 275 \mathrm{~V} / 50 \mathrm{~Hz}$, X2 Class.

Used RC elements are officially marketed as EMI suppression capacitors (Kemet, 2015). Resistance and capacitor are in serial connection and encapsulated. Both elements are very similar and produced by the same manufacturer. The only difference is in the capacity parameter of the elements. 


\section{Test results}

Table 1 Overall test results

RC SUPRESSION TEST - FINAL RESULTS

\begin{tabular}{|c|c|c|c|c|c|c|c|c|c|}
\hline & \multirow[t]{2}{*}{ No. } & \multirow[t]{2}{*}{ Description } & \multirow[t]{2}{*}{ RC Element } & \multirow[t]{2}{*}{ TO $\left({ }^{\circ} \mathrm{C}\right)$} & \multirow[t]{2}{*}{ T5 $\left({ }^{\circ} \mathrm{C}\right)$} & \multirow{2}{*}{$\begin{array}{c}\Delta \text { T0-T5 } \\
\left({ }^{\circ} \mathrm{C}\right)\end{array}$} & \multicolumn{2}{|c|}{ A-measure (mm) } & \multirow{2}{*}{$\underset{(\mathrm{mm})}{\Delta \mathrm{A}}$} \\
\hline & & & & & & & before test & after test & \\
\hline \multirow{19}{*}{ TEST 01} & 1 & $077 B 6000+R C$ & $39 \Omega+0.68 \mu \mathrm{F}$ & $-19,06$ & $-22,69$ & $-3,63$ & 1,91 & 1,55 & 0,36 \\
\hline & 2 & 077B6000 + RC & $39 \Omega+0.68 \mu \mathrm{F}$ & $-18,95$ & $-22,69$ & $-3,74$ & 1,95 & 1,58 & 0,37 \\
\hline & 3 & $077 \mathrm{~B} 6000+\mathrm{RC}$ & $39 \Omega+0.68 \mu \mathrm{F}$ & $-17,88$ & $-21,63$ & $-3,75$ & 1,89 & 1,56 & 0,33 \\
\hline & 4 & 077B6000 + RC & $39 \Omega+0.68 \mu \mathrm{F}$ & $-19,27$ & $-21,29$ & $-2,02$ & 1,93 & 1,64 & 0,29 \\
\hline & 5 & $077 B 6000+R C$ & $39 \Omega+0.68 \mu \mathrm{F}$ & $-18,95$ & $-23,18$ & $-4,23$ & 1,89 & 1,44 & 0,45 \\
\hline & 6 & $077 B 6000+R C$ & $39 \Omega+1.00 \mu \mathrm{F}$ & $-19,38$ & $-22,10$ & $-2,72$ & 1,87 & 1,59 & 0,28 \\
\hline & 7 & $077 B 6000+R C$ & $39 \Omega+1.00 \mu \mathrm{F}$ & $-19,60$ & $-23,42$ & $-3,82$ & 1,92 & 1,50 & 0,42 \\
\hline & 8 & 077B6000 + RC & $39 \Omega+1.00 \mu \mathrm{F}$ & $-19,27$ & $-22,46$ & $-3,19$ & 1,89 & 1,52 & 0,37 \\
\hline & 9 & $077 B 6000+R C$ & $39 \Omega+1.00 \mu \mathrm{F}$ & $-19,49$ & $-22,81$ & $-3,32$ & 1,88 & 1,50 & 0,38 \\
\hline & 10 & $077 B 6000+R C$ & $39 \Omega+1.00 \mu \mathrm{F}$ & $-19,27$ & $-23,42$ & $-4,15$ & 1,88 & 1,44 & 0,44 \\
\hline & & \multicolumn{2}{|c|}{ Average $01-10$ (Test no.01 all samples) } & $-19,11$ & $-22,57$ & $-3,46$ & 1,90 & 1,53 & 0,37 \\
\hline & & \multicolumn{2}{|c|}{ MIN 01-10 (Test no.01 all samples) } & $-19,60$ & $-23,42$ & $-4,23$ & 1,87 & 1,44 & 0,28 \\
\hline & & \multicolumn{2}{|c|}{ MAX 01-10 (Test no.01 all samples) } & $-17,88$ & $-21,29$ & $-2,02$ & 1,95 & 1,64 & 0,45 \\
\hline & & \multicolumn{2}{|c|}{ Average $01-05(39 \Omega+0.68 \mu \mathrm{F})$} & $-18,82$ & $-22,30$ & $-3,47$ & 1,91 & 1,55 & 0,36 \\
\hline & & \multicolumn{2}{|c|}{ MIN 01-05 $(39 \Omega+0.68 \mu \mathrm{F})$} & $-19,27$ & $-23,18$ & $-4,23$ & 1,89 & 1,44 & 0,29 \\
\hline & & \multicolumn{2}{|c|}{ MAX 01-05 $(39 \Omega+0.68 \mu F)$} & $-17,88$ & $-21,29$ & $-2,02$ & 1,95 & 1,64 & 0,45 \\
\hline & & \multicolumn{2}{|c|}{ Average $06-10(39 \Omega+1.00 \mu \mathrm{F})$} & $-19,40$ & $-22,84$ & $-3,44$ & 1,89 & 1,51 & 0,38 \\
\hline & & \multicolumn{2}{|c|}{ MIN 06-10 $(39 \Omega+1.00 \mu \mathrm{F})$} & $-19,60$ & $-23,42$ & $-4,15$ & 1,87 & 1,44 & 0,28 \\
\hline & & \multicolumn{2}{|c|}{ MAX 06-10 $(39 \Omega+1.00 \mu F)$} & $-19,27$ & $-22,10$ & $-2,72$ & 1,92 & 1,59 & 0,44 \\
\hline \multirow{13}{*}{ TEST 02} & 11 & 077B6000 & $\mathrm{N} / \mathrm{A}$ & $-19,38$ & $-22,46$ & $-3,08$ & 1,92 & 1,57 & 0,35 \\
\hline & 12 & 077B6000 & $\mathrm{N} / \mathrm{A}$ & $-19,49$ & $-22,58$ & $-3,09$ & 1,89 & 1,51 & 0,38 \\
\hline & 13 & 077B6000 & N/A & $-19,06$ & $-22,10$ & $-3,04$ & 1,95 & 1,62 & 0,33 \\
\hline & 14 & 077B6000 & $\mathrm{N} / \mathrm{A}$ & $-19,27$ & $-22,10$ & $-2,83$ & 1,89 & 1,48 & 0,41 \\
\hline & 15 & 077B6000 & N/A & $-20,27$ & $-22,34$ & $-2,07$ & 1,94 & 1,58 & 0,36 \\
\hline & 16 & 077B6000 & N/A & $-19,27$ & $-22,22$ & $-2,95$ & 1,94 & 1,63 & 0,31 \\
\hline & 17 & 077B6000 & N/A & $-20,04$ & $-22,58$ & $-2,54$ & 1,94 & 1,54 & 0,40 \\
\hline & 18 & 077B6000 & $\mathrm{N} / \mathrm{A}$ & $-18,73$ & $-22,34$ & $-3,61$ & 1,93 & 1,60 & 0,33 \\
\hline & 19 & 077B6000 & N/A & $-19,82$ & $-23,54$ & $-3,72$ & 1,88 & 1,42 & 0,46 \\
\hline & 20 & 077B6000 & $\mathrm{N} / \mathrm{A}$ & $-19,49$ & $-23,06$ & $-3,57$ & 1,87 & 1,46 & 0,41 \\
\hline & & \multicolumn{2}{|c|}{ Average $11-20$ (Test no.02 all samples) } & $-19,48$ & $-22,53$ & $-3,05$ & 1,92 & 1,54 & 0,37 \\
\hline & & MIN 11-20 & & $-20,27$ & $-23,54$ & $-3,72$ & 1,87 & 1,42 & 0,31 \\
\hline & & MAX 11-20 & & $-18,73$ & $-22,10$ & $-2,07$ & 1,95 & 1,63 & 0,46 \\
\hline
\end{tabular}

T0 - Cut-out temperature at initial (0 cycles) pressure/temperature scanning

T5 - Cut-out temperature at final (300.000 cycles) pressure/temperature scanning 

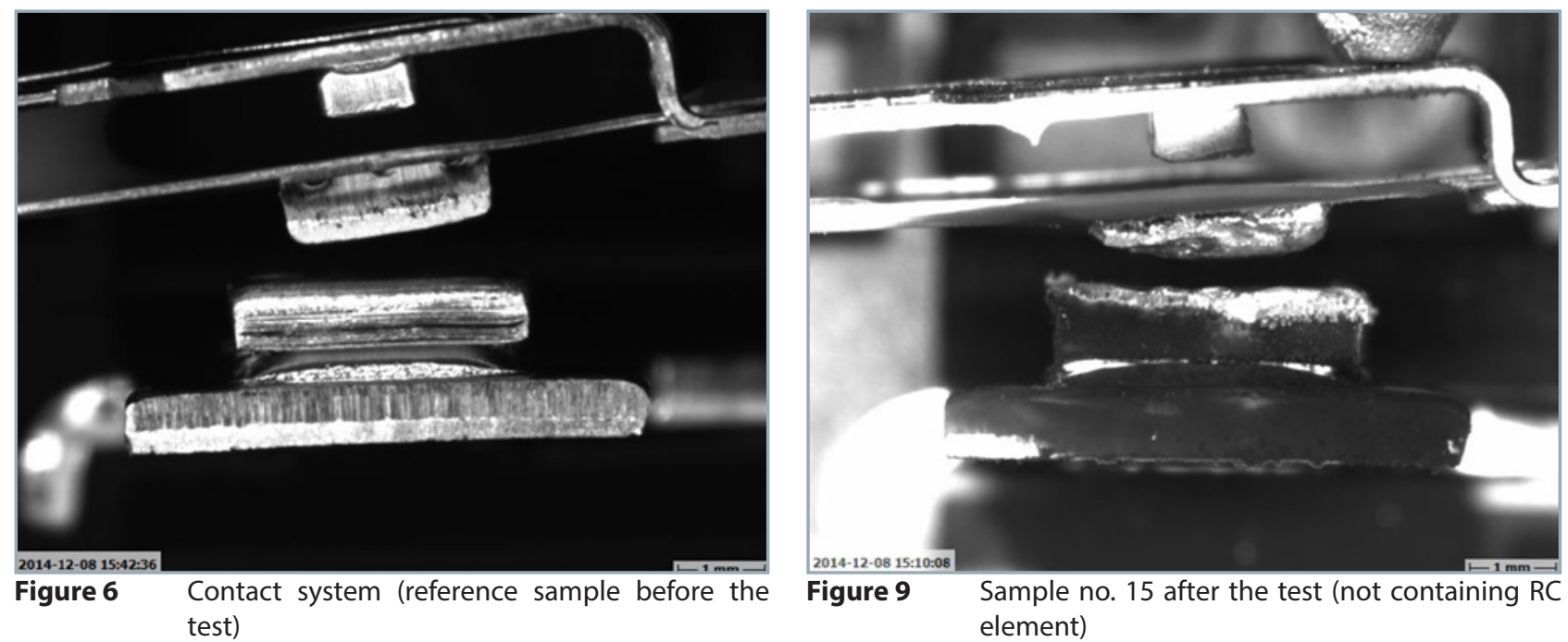

Figure 9 Sample no. 15 after the test (not containing RC element)

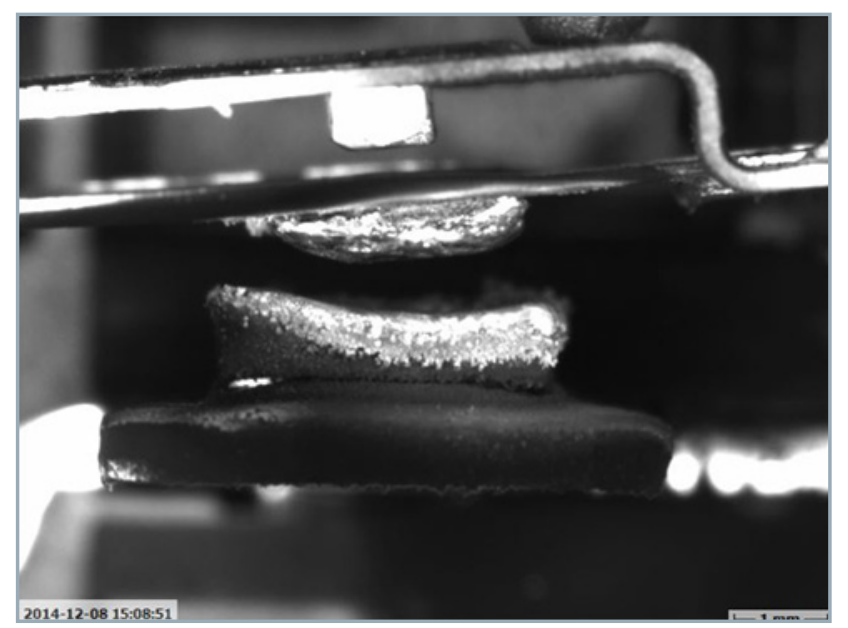

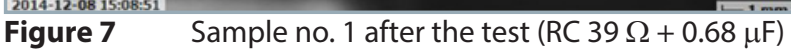

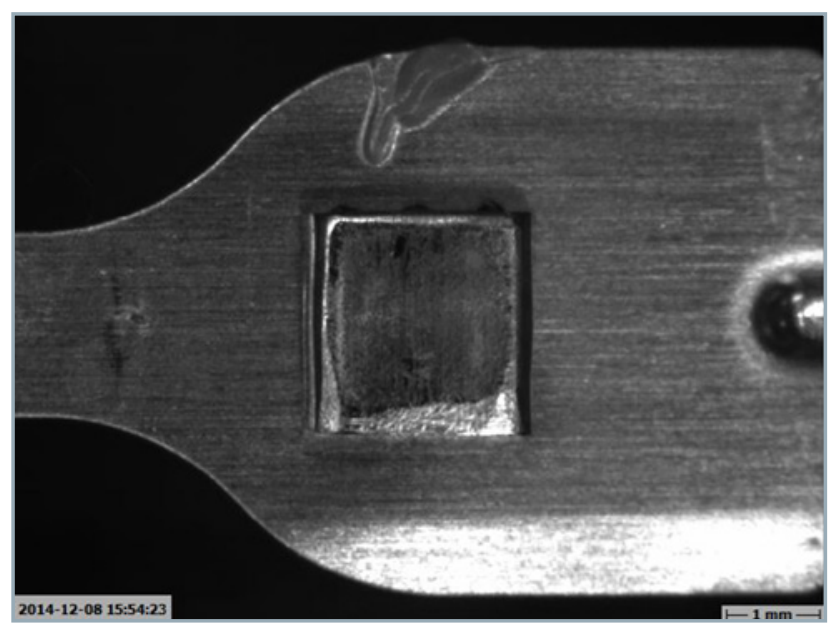

Figure 10 Contact Spring (reference sample before the test)

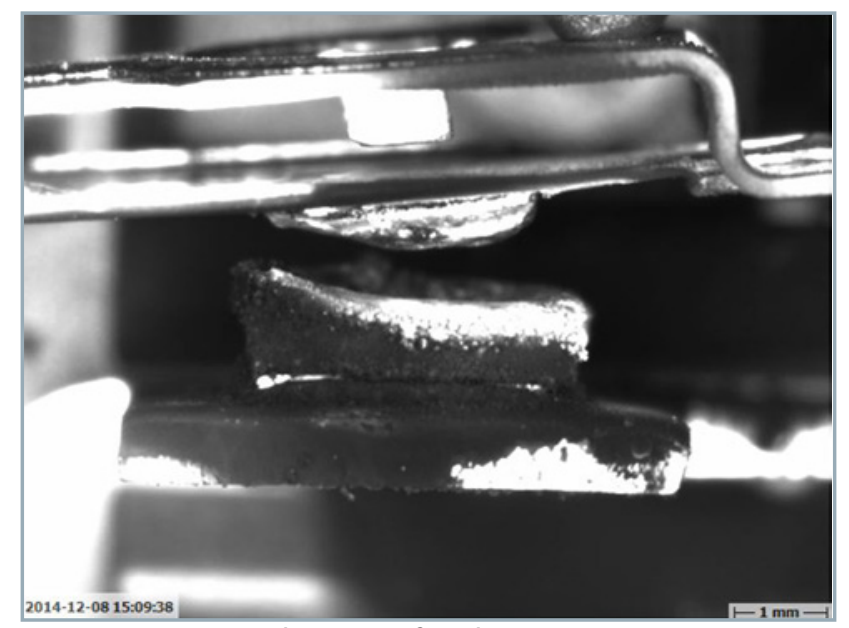

Figure 8 Sample no. 10 after the test (RC $39 \Omega+1.00 \mu \mathrm{F})$

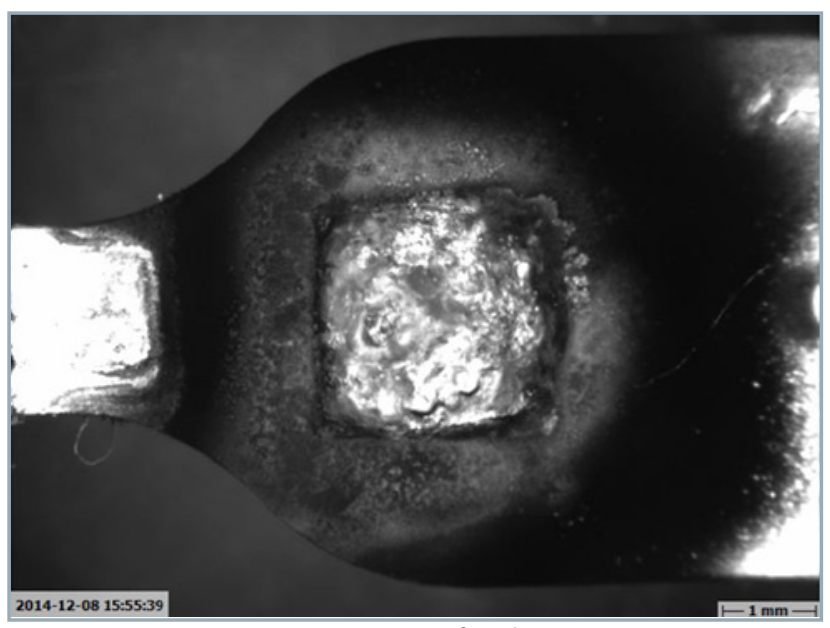

Figure 11

Contact Spring no. 1 after the test (RC $39 \Omega+0.68 \mu \mathrm{F})$ 


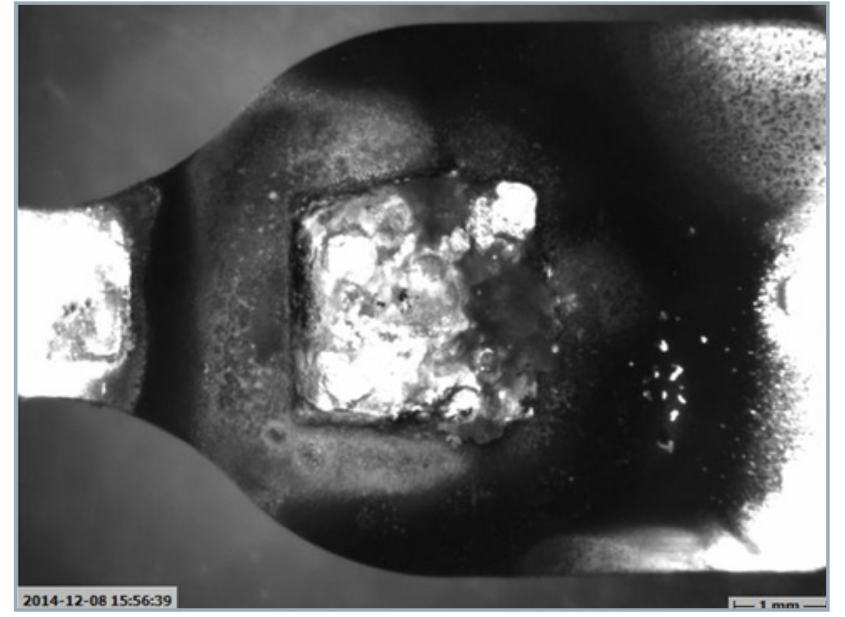

Figure 12 Contact Spring no. 10 after the test (RC $39 \Omega+$ $1.00 \mu \mathrm{F})$

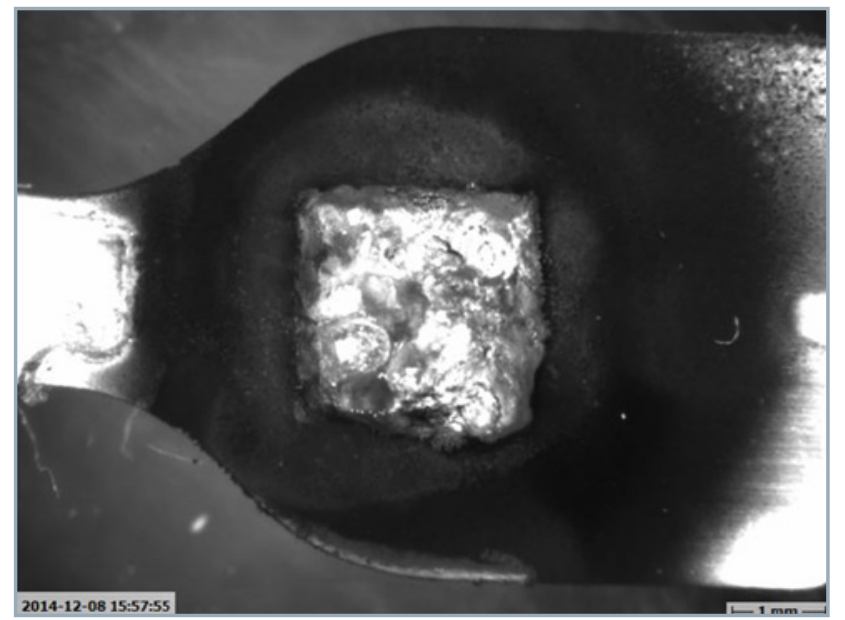

Figure 13 Contact Spring no. 15 after the test (not containing RC element)

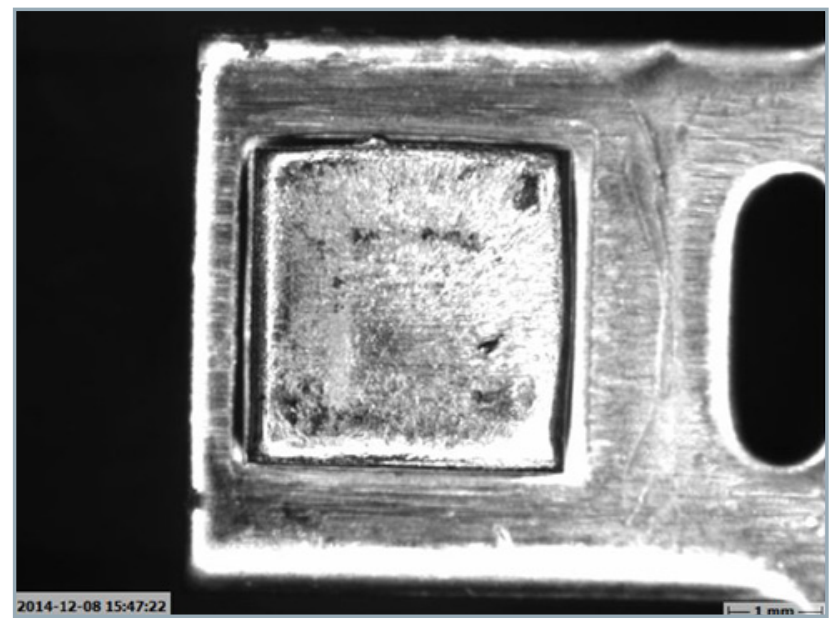

Figure 14 Terminal (reference sample before the test)

\section{Discussion}

Electric arc during the cut-out lasts longer in normal operation, however, RC element helps to reduce it. The situation is worse during contact make when contact

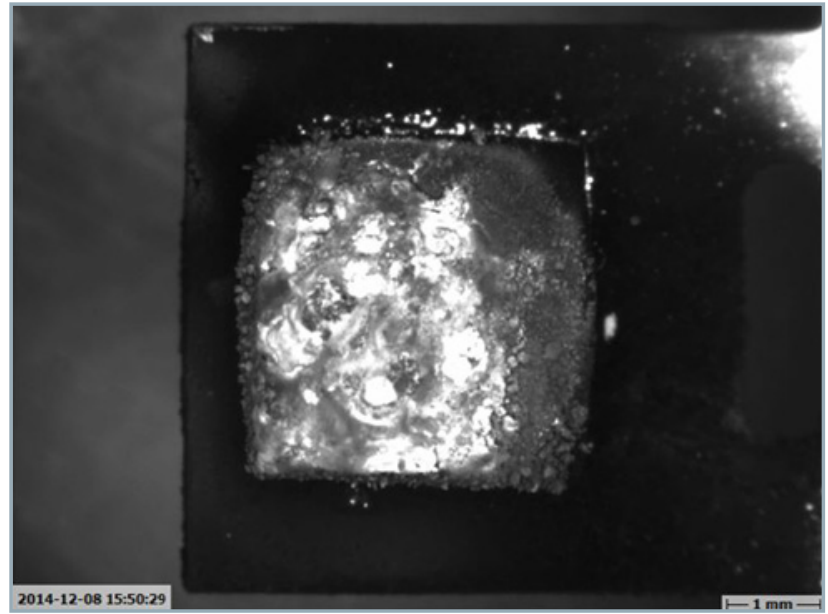

Figure 15

Terminal no. 1 after the test (RC $39 \Omega+0.68 \mu \mathrm{F})$

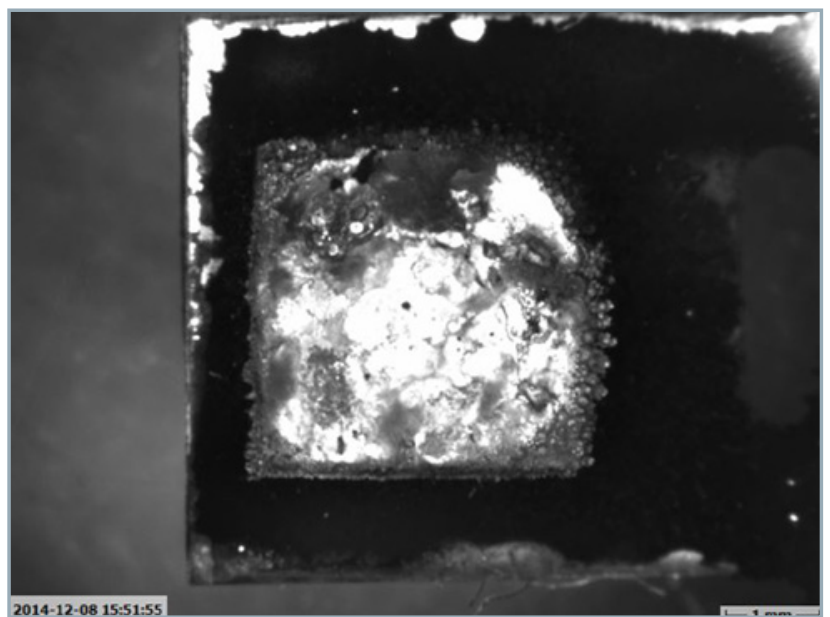

Figure 16 Terminal no. 10 after the test $(\mathrm{RC} 39 \Omega+1.00 \mu \mathrm{F})$

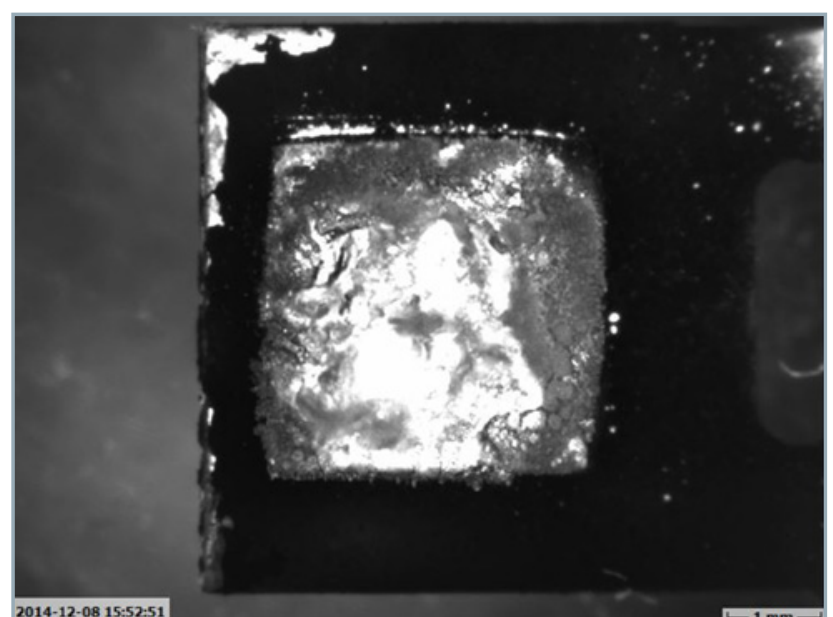

Figure 17

Terminal no. 15 after the test (not containing RC element)

bouncing occurs as mentioned by Kratzshmar (Kratzshmar et al., 2010). Just before the make, contacts are becoming very close just and after the initial make, contact bounces back because of the spring characteristics of the contact parts. This may occur several times until the final make is performed (Danfoss, 1998). This effect creates a multiple 
number of smaller arcs between the contacts; it consequently heats up the contact area and $\mathrm{AgSnO}_{2}$ layer gets melted in a small contact area. The arcing during make is even boosted by RC element as it discharges its capacitor through a resistance and contacts. Forces applied on contacts during make are splashing away the melted $\mathrm{AgSnO}_{2}$. Splashing of the silver does not occur during contact break (cut-out) as there are no forces applied on contacts. RC Element has a positive influence regarding the reduction of the electromagnetic interference (radio noise) by arc time reduction during cut-out. On the other hand, RC element increases contact wear and reduces contact life time by discharging its capacity through the resistance and contacts during cut-in and splashing away the $\mathrm{AgSnO}_{2}$ contact layer.

\section{Conclusion}

All 20 samples of 2 batches have passed 300000 cycles (Danfoss, 2012). The test results showed no significant improvement of the contact wear by using of the RC element.

The A-measure change is considered the very same for the both sets. The difference is statistically insignificant. In average, thermostats with RC elements wired parallel to the main contacts showed slightly higher temperature drift $\left(-3.46^{\circ} \mathrm{C}\right)$ than the standard samples $\left(-3.05^{\circ} \mathrm{C}\right)$. Maximum temperature drift was higher in thermostats with $\mathrm{RC}$ elements $\left(-4.23{ }^{\circ} \mathrm{C}\right)$ than in standard samples $\left(-3.72{ }^{\circ} \mathrm{C}\right)$. Difference in minimum drift is statistically insignificant. Detailed pictures taken after the test on sub-assemblies and parts of the samples no.1; 10 and 15 confirmed the results. The wear on all 3 disassembled and measured samples was very similar.

The use of RC elements for cold appliances thermostats is not considered a reasonable measure. There was found no improvement of the contact wear or thermostat lifetime. Improvement of the Electro Magnetic Interference is not needed as the contact bouncing is reduced to minimum by correct set-up of forces in the contact system. Contact profile with $\mathrm{AgSnO}_{2}$ layer provides a sufficient prevention against contact wear (Kratzshmar et al., 2010).

\section{Acknowledgment}

This work was performed at Danfoss Appliance Controls facilities in Zlaté Moravce, Slovak Republic. Knowledge, material and technical support is gratefully acknowledged.

\section{References}

ALTHOUSE, A. D. - TURNQUIST, C. H. - BRACCIANO, A. F. 2004. Modern refrigeration and air conditioning. $18^{\text {th }}$ ed. Tinley Park, IL : Goodheart-Wilcox Company Inc.

BOŠANSKÝ, M. - VANYA, A. - HUDÁKOVÁ, M. - MALÝ, V. 2012.Tverdyje pokrytia kak vozmožnost' povyšenia nagruzočnoj sposobnosti vypuklo-vognytych zaceplenii vzaimodejstvujuščich s vio-maslanoj smaskoj. In Visnik nacional'novo techničnovo universitetu "XIII" 2012. Charkiv : Nacional'nyj techničeskij univesitet, 35, pp. 16-24.

DANFOSS. 1998. Thermostats and pressure controls - Facts and functions. Nordborg: Danfoss A/S.

DANFOSS. 2006. Table of vapour pressure for refrigerants used for charging 077B thermostats. Nordbord: Danfoss A/S.

DANFOSS. 2012. Test of 077B thermostat. $9^{\text {th }}$ ed. Nordborg : Danfoss $\mathrm{A} / \mathrm{S}$.

IEC. 1999. EN/IEC 60730-1. Automatic electrical controls for household and similar use, Part 1: General requirements. Brussels : CENELEC.

IEC. 2004. EN/IEC 60335-1 Household and similar electrical appliances - Safety, part 1: General requirements. Geneva : IEC.

KEMET. 2015. Metallized Polypropylene Film EMI Suppression Capacitors. Retrieved from: www.kemet.com. Accessed 27 November 2015.

KUČERA, M. - CHOTĚBORSKÝ, R. 2013. Analysis of the process of abrasive wear under experimental conditions. In Scientia agriculturae bohemica, 2013, no. 44, pp. 102-106.

KRATZSHMAR, A. et al., 2010. Basic investigation on the behaviour of advanced $\mathrm{Ag} / \mathrm{SnO}_{2}$ materials for contactor applications. Charleston (SC), IEEE, 2010, pp. 127-133.

MÁCHAL, P. - TKÁČ, Z. - KOSIBA, J. - JABLONICKÝ, J. - HUJO, L. KUČERA, M. - TULÍK, J. 2013. Design of a laboratory hydraulic device for testing of hydraulic pumps. In Acta Universitatis Agriculturae et Silviculturae Mendelianae Brunensis., vol. 61, 2013, pp. 1313-1319.

PANCON. 2015. Type Q/QRL Quencharc Capacitor. RC Snubber Network. Retrieved from: www.pancorp.com. Accessed 27 November 2015.

UL. 2010. UL 873. Standard for temperature indicationg and regulating equipment. Chicago (IL) : UL Inc. 